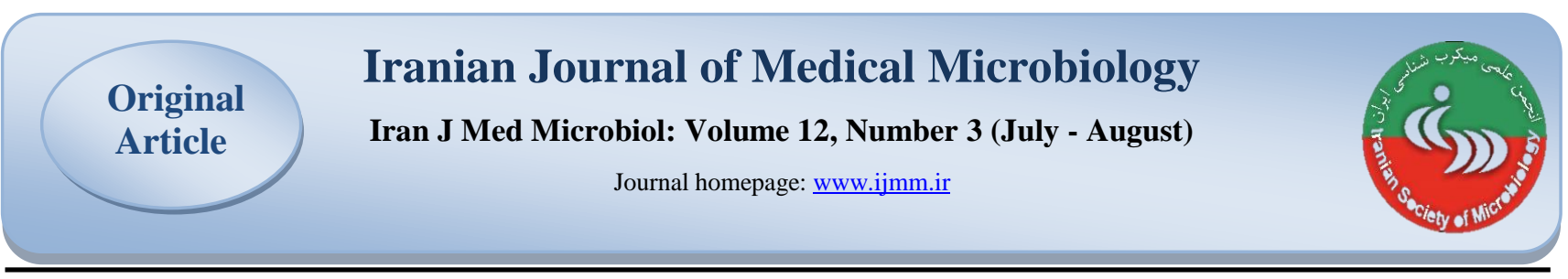

\title{
Biofilm Formation of Salmonella typhimurium on Stainless Steel in Red Meat Model and the Effect of Bacteriophage on Bacterial Biofilm
}

\author{
Hossein Tajik, Mehran Moradi, Mostafa Alipour, Hadi Ghasemmahdi
}

Department of Food Hygiene and Quality Control, Faculty of Veterinary Medicine, Urmia University, Urmia, Iran

\section{Article Information}

\section{Article history:}

Received: 2017/04/09

Accepted: 2018/07/02

Available online: 2018/10/11

\section{Article Subject:}

Clinical Microbiology

\section{IJMM 2018; 12(3): 179-188}

Corresponding author:

\section{Mehran Moradi}

Department of Food Hygiene and Quality Control, Faculty of Veterinary Medicine, Urmia University, Urmia, Iran

Tel: 044-31942633

Email:

m.moradi@urmia.ac.ir

Use your device to scan and read the article online

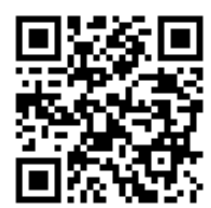

\section{Abstract}

Background and Aims: The application of bacteriophage to control and removal of bacterial biofilm is a novel method. The goal of this study was to investigate the effect of the Salmonella typhimurium bacteriophage against biofilm of a multidrug resistance (MDR) Salmonella formed on stainless steel in beef broth.

Materials and Methods: One and 7 days old biofilm were grown at 15,8 and $4{ }^{\circ} \mathrm{C}$, on the stainless steel in beef broth and the effects of different bacteriophage concentrations $\left(10^{3}, 10^{5}\right.$ and $10^{7} \mathrm{PFU} / \mathrm{mL}$ ) with two contact times (10 and $\left.15 \mathrm{~min}\right)$ were assayed.

Results: Results showed that Salmonella can adhere to stainless steel and form biofilm in the beef broth which was significantly influenced by temperature. Higher biomass of biofilm was developed at 15,4 and $8{ }^{\circ} \mathrm{C}$, respectively. One-day-old is less dense ( 1 logarithmic cycle) than 7-day-old biofilm. No significant difference $(P>0.05)$ in biofilm reduction was observed in samples treated with different concentration as compared with control. Statistical differences were also not observed in the different contact time (10 and $15 \mathrm{~min})$.

Conclusions: These results indicated that there was no significant reduction in MDR Salmonella biofilm population developed on stainless steel in the beef broth after using the bacteriophage; it is needed to investigate some combination procedures or increase contact time to improve the biofilm removal activity of bacteriophage.

Keywords: Bacteriophage, Salmonella typhimurium, Biofilm, Red meat

How to cite this article:

\section{Tajik H, Moradi M, Alipour M, Ghasemmahdi H. Biofilm Formation of Salmonella} typhimurium on Stainless Steel in Red Meat Model and the Effect of Bacteriophage on Bacterial Biofilm. Iran J Med Microbiol. 2018; 12 (3) :179-188 


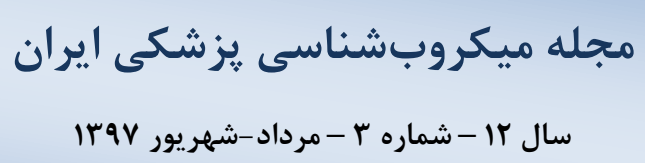

Journal homepage: www.ijmm.ir
مقاله

يزّوهشى

\section{تشكيل بيوفيلم سالهونلا تيفىوريوم در سطح استيل زنخنزن در مدل كوشت قرمز و اثرات باكتريوفاز بر بيوفيلم باكترى}

حسين تاجيك، مهران مرادى، مصطفى عليبور، هادى قاسممهدى

كروه بهداشت و كنترل كيفى موادغذايى، دانشكدة داميزشكى، دانشعاه اروميه، اروميه، ايران

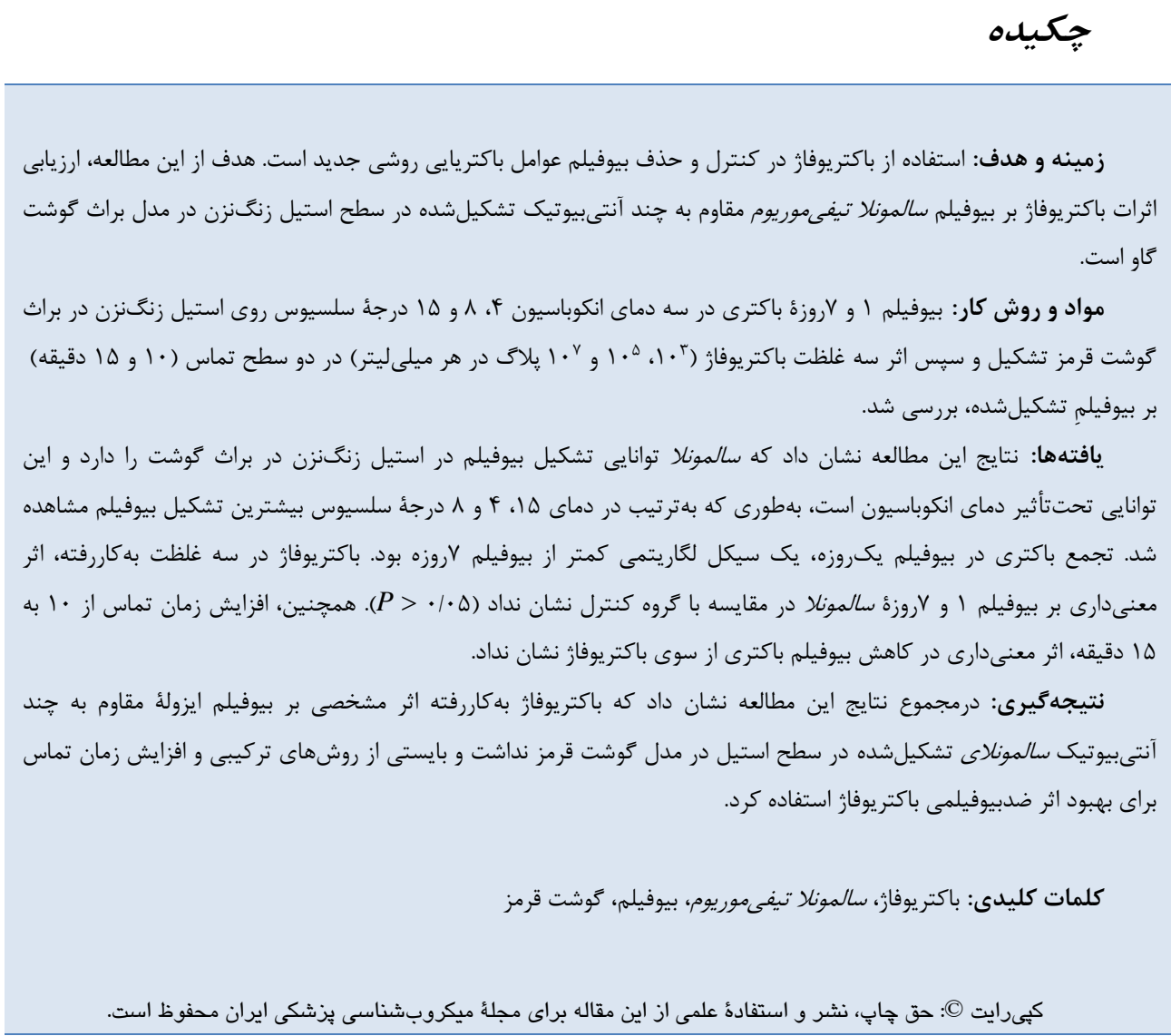
اطلاعات مقاله
تاريخجهُ مقاله

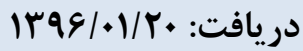

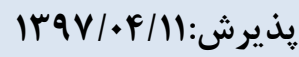
انتشار آنلاين: و
موضوع:

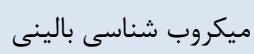
IJMM1397;12(3): 179-188
نويسندهُ مسئول:
مهران مر ادى
كروه بهداشت و كنترل كيفى موادغذايى، مرادي،
دانشكدة داميزشكى، دانشخاه اروميه،
اروميه، ايران

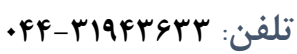
يست الكترونيك:
moradi.mehran@yahoo.com

كيىرايت C: حق جاب، نشر و استفادهُ علمى از اين مقاله براى مجلهُ ميكروبشناسى بزشكى ايران محفوظ است.

مقله مه

آنها با عوامل ضدميكروبى مىشود. ميكرواركانيسمها از جمله ميكرواركانيسمهاى بيمارىزا و ايجادكننده فساد، توانايى تشكيل

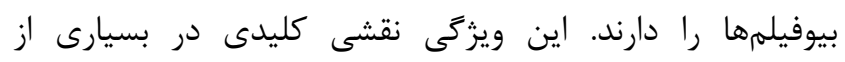
عفونتها و آلودگىهاى ناشى از محصولات غذايى دارد. تشكيل بيوفيلم براى باكترى تحت شرايط محيطى سخت، استراتزىاى

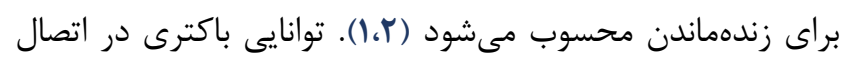

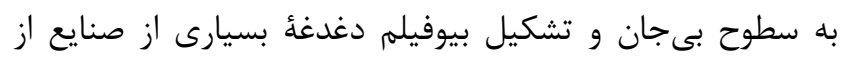

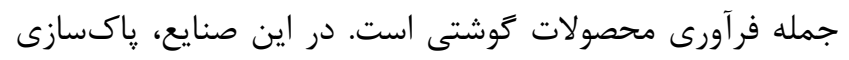

بيوفيلم ساختار يلىساكاريدى است كه از طريق جمعيتى از

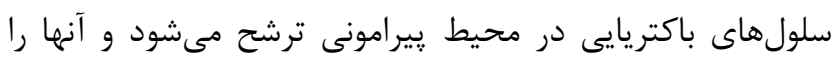
نسبت به شرايط محيطى مقاوم مى كند. شكل گيرى و كسترش بيوفيلم تابع عوامل متعددى از جمله نوع باكترى، خصوصيات

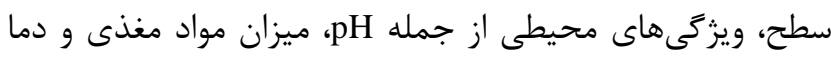

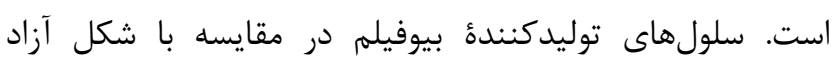
باكترى، مقاومت بالايى نسبت به عوامل ضدميكروبى دارند؛ جراكه داراى ويزگگىهايى هستند كه باعث كاهش و يا جلو 
نانوامولسيون و سورفكتانتها موردتوجه قرار گرفتهاند. باكتريوفازها نيز بهعنوان دشمن طبيعى باكترىها از تركيبات ضدميكروبى طبيعى با قابليت حذف و كنترل بيوفيلم شناخته شدهاند (1).

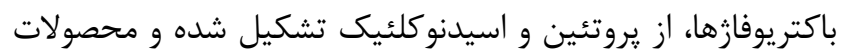
حاصل از شكستن آنها، اسيدهاى آمينه و اسيد نوكلئيك است؛ بنابراين باعنوان يك زنوبيوتيك (Xenobiotics) مطرح نيستند.

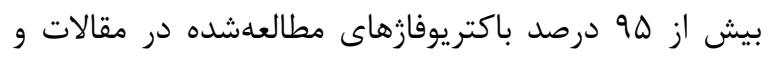
تقريبا تمام فازهاى مهلم و مرتبط با باكترىهاى بيمارىزا با منشأ

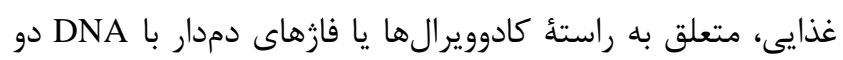
رشتهاى هستند كه براساس اندازه دم به سه خانواده تقسيم

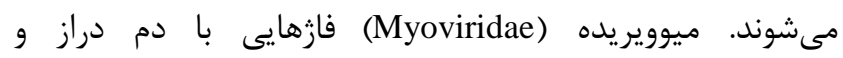
قابلانقباض هستند؛ (Siphoviridae) ذُمى دراز دارند ولى قابلى

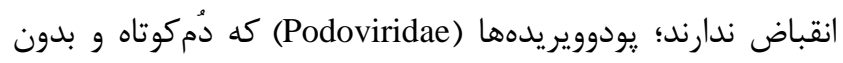

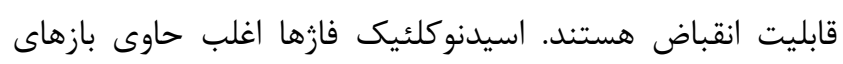
غيرمعمول يا تغييريافته است. اين بازهاى تغييريافته اسيدنوكلئيك

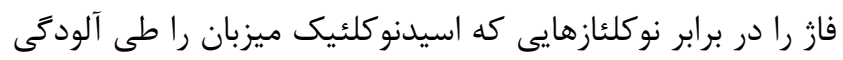

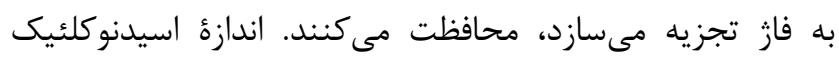

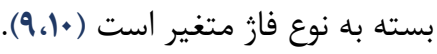

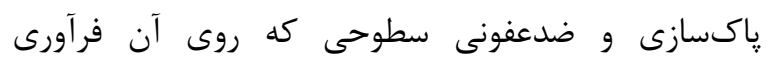
موادغذايى انجام مىشود از آلودگى محصولات غذايى به عوامل

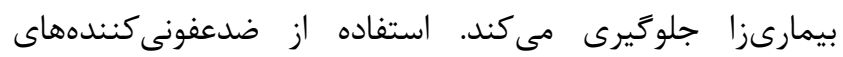
شيميايى به ايجاد مقاومت در تعدادى از عوامل بيمارىز منا منجر شده است؛ بنابراين بهكارگيرى روشهائ به جديد براى ضدعفونى كردن سطوح لازم است. اما زمانى كه باكترىها روى سطى سطوح بيوفيلم تشكيل مىدهند، زدودن آنها با ضدعفونى كنندهها سخت

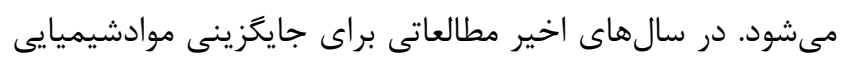
با باكتريوفازها بهمنظور حذف عوامل توليدكننده بيوفيلم از سطوح انجام شده است. بر اين اساس مطالعات مختلفى در زمينهُ استفاده از باكتريوفاز در حذف و كنترل بيوفيلم عوامل بيمارىزا از جمله

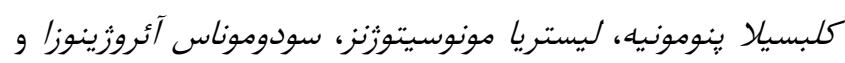

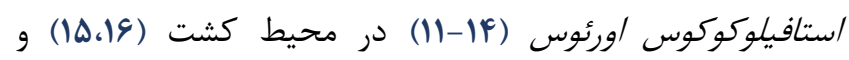
مدلهاى غذايى (IV،IN) انجام شده و موفقيتهايى نيز به دست دوست آمده است. اثربخشى باكتريوفاز بر بيوفيلم تحت تأثير ويزگى هاى

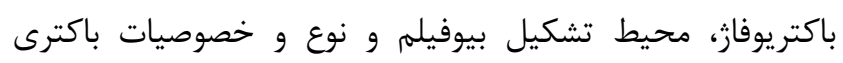
مدنظر است. در حال حاضر، استفاده تجارى از باكتريوفاز در

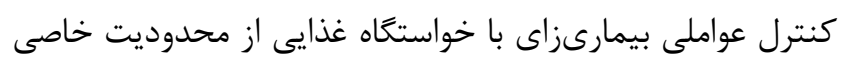

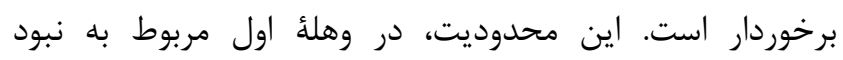
اطلاعات كافى و جامع درباره كاربرد اين عوامل در موادغذايى
ناقص سطوح منجر به تجمع مواد آلى و غيرآلى مىشود و حضور

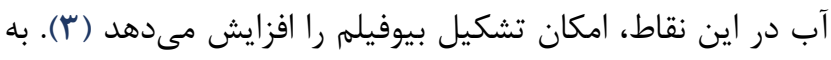
نظر مىرسد يكى از علل بقاى ميكروار كانيسم در محيط بهويزه در

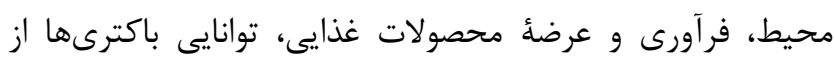
جمله سالمونلا در تشكيل بيوفيلم باشد. از سويى اهميت آلودىى وحى

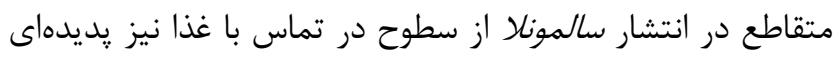

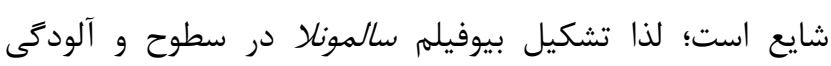
متقاطع با اين سطوح يك روش بالقوه آلودگى محصولات غذايى به

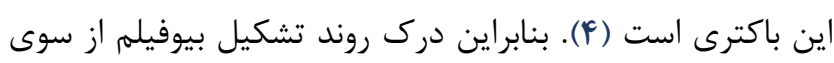

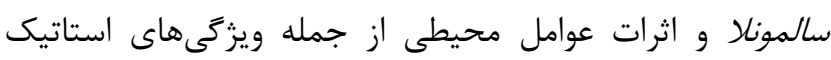

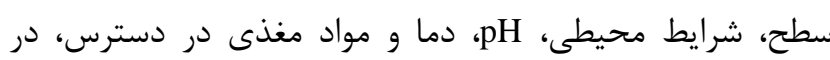

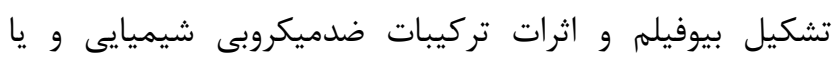
طبيعى، اهميت بسزايى در حذف و ريشهكن كردن باكترى دارد

آلودگى ميكروبى در كارخانهاى فرآورى و كشتاركاههاى

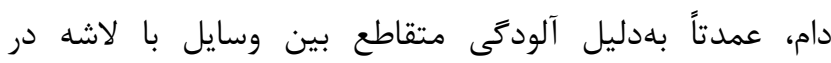
بخشهاى مختلف فرآورى اتفاق مى افتد. امكان آلودگى محصولات خام به باكترىهايى با توانايى تشكيل بيوفيلم كه بهصورت مختلط

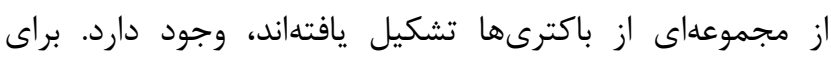
كنترل بيوفيلم در جنين واحدهايى، داشتن دانش لازم در زمينه محل تشكيل بيوفيلم و ميكروارگانيسمهاى دخيل ضرورى است. از

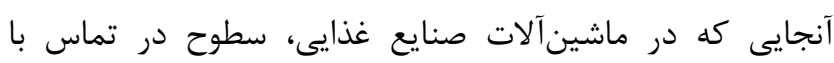
موادغذايى اغلب از جنس استيل زنتخنزن است، استفاده مكرر از اين سطوح، باعث ايجاد خراشيدگى و زبرى شده و به اين خاطر لكؤ موادغذايى روى اين سطوح باقى مانده و باعث افزايش توانايى

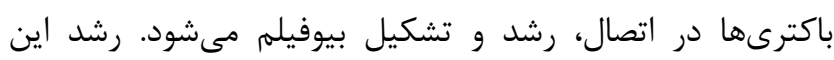

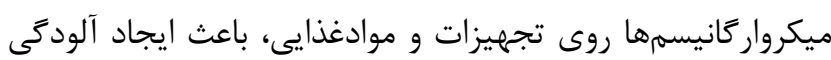
ميكروبى در محصول شده و در نتيجه منجر به كاهش مدتزمان نتحهدارى محصول و افزايش شيوع بيمارىهاى ناشى از غذا مى دهود

.$(9 . \vee)$

در ساليان اخير، استفاده از روشهاى جديد براى كنترل فرم آزاد و بيوفيلم سالمونلا در موادغذايى مطرح شده است. از اين روشها مىتوان به استفاده از عاز ازن، اولتراسوند، آب الكتروليز،

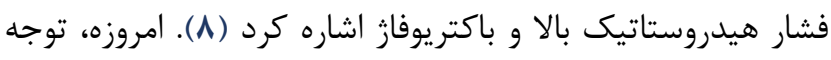
ويزهاى به استفاده از اسانس و عصارههاى گياهى در جلوخيرى و كنترل بيوفيلم باكترىها مىشود. در كنار تركيبات كياهى،

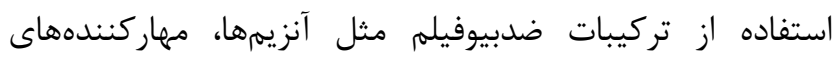

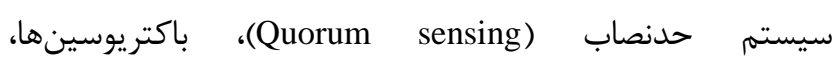


با فيلتر سرسرنكى r/T/• ميكرومتر فيلتر گشت. محلول باكتريوفاز

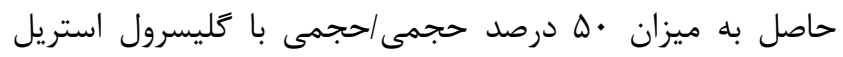

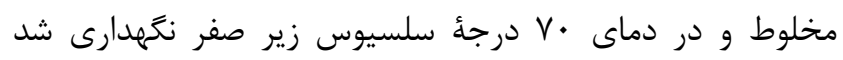

1.9

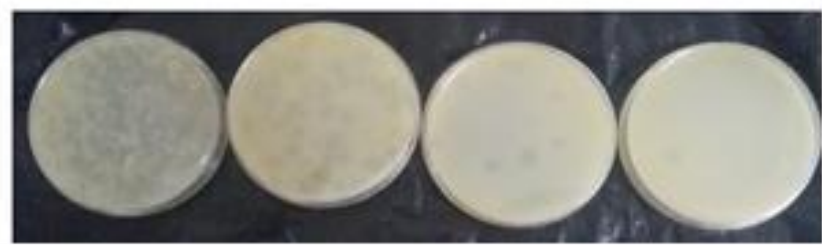

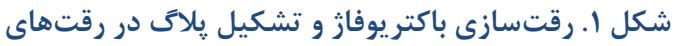

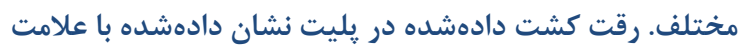
ستاره، بهعنوان رقت اصلى براى تهيئ استوك استفاده شد.

\section{تهيئَ براث كَشت كاو}

براى تهيئ براث گَوشت، كوشت تازء كاو از كشتاركاه تهيه

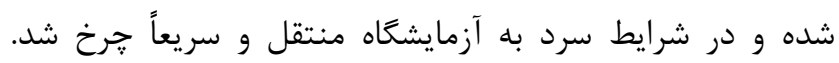

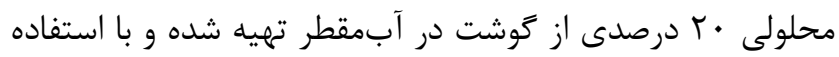

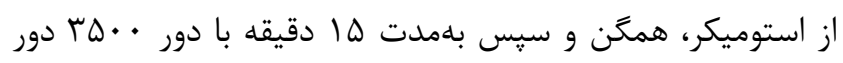

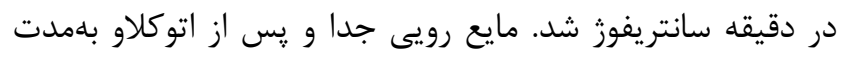

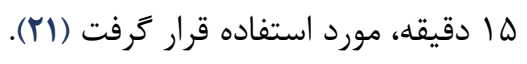

\section{تشكيل بيوفيلم}

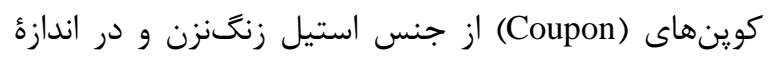

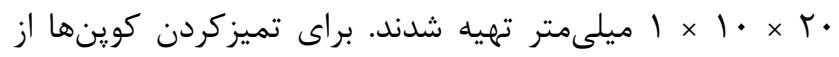

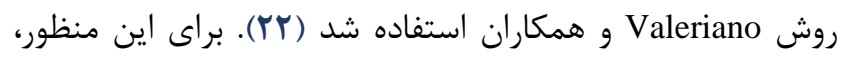

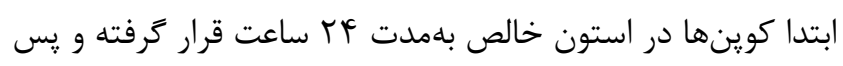

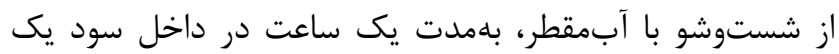

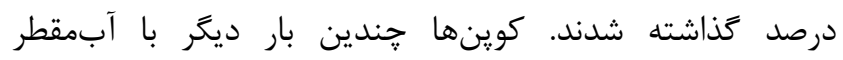

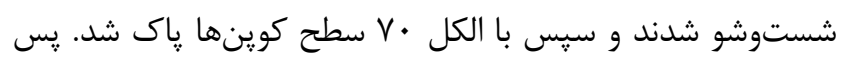

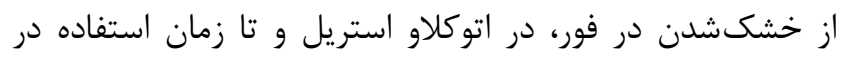

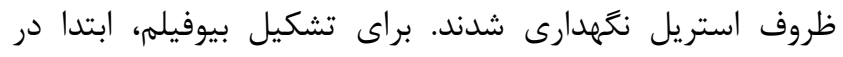

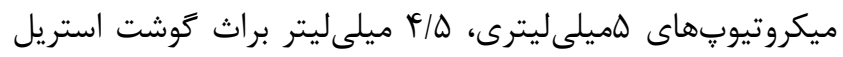

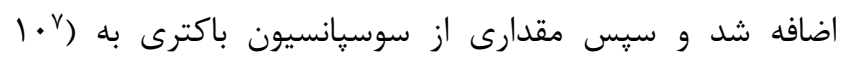

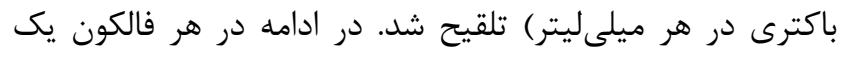

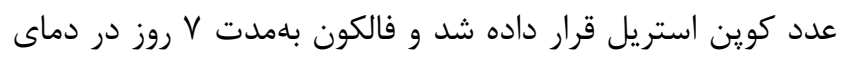

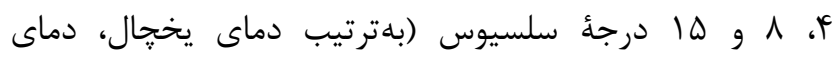

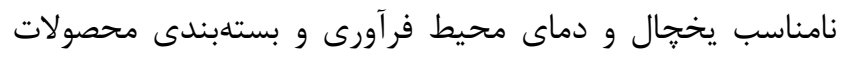

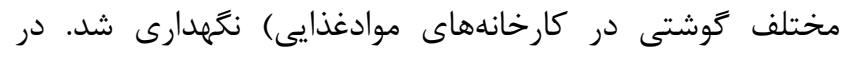

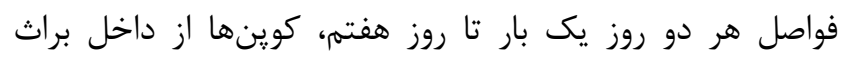

است. تاكنون مطالعهاى در زمينهُ اثرات دماى انكوباسيون بر روند

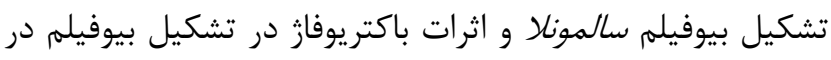

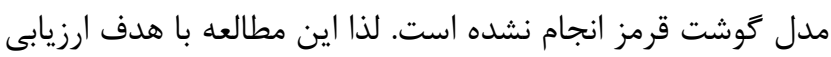
امكان تشكيل بيوفيلم و اثرات باكتريوفاز بر بيوفيلم سالمونلا

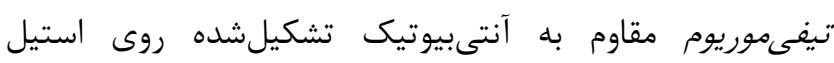
زنغنزن در مدل براث كوشت گاو انجام يذيرفت.

$$
\text { مواد و روشهان در مدر براث }
$$

\section{تهيه و آمادهسازى باكترى}

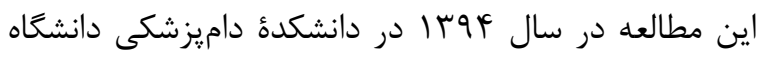

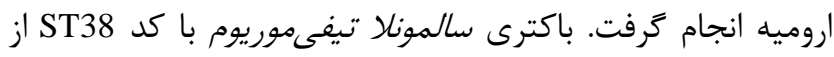

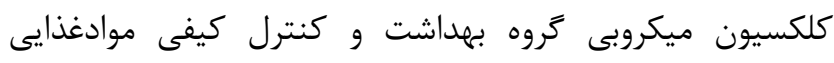

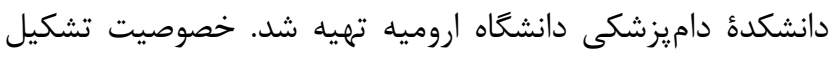

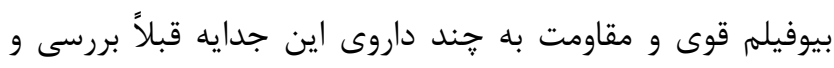

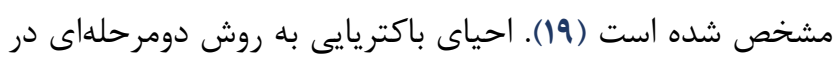

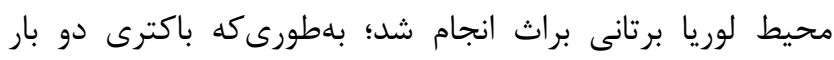

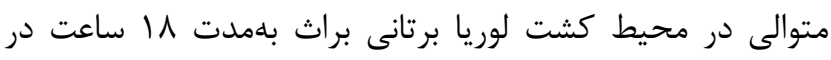

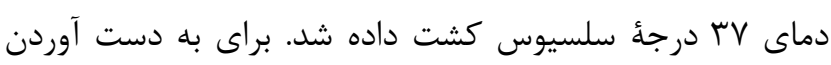

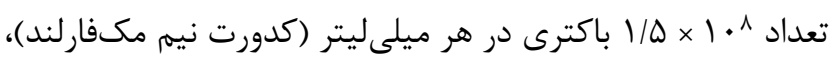

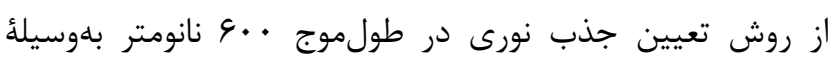
اسيكتوفتومتر و كشت باكترى استفاده شد.

\section{تهيئ استوك باكتر يوفاز}

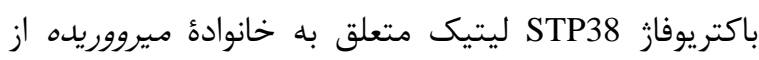

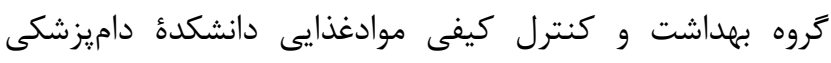

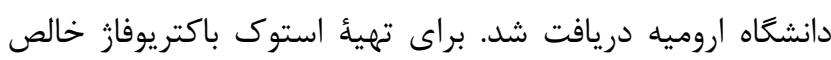

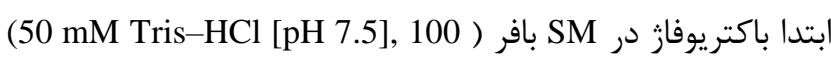

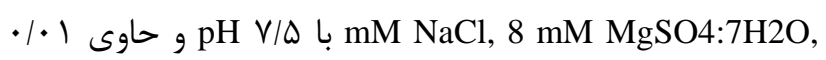
درصد زلاتين رقتسازى شد و سيس به روش كشت دولايه كشت

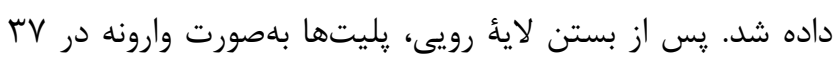

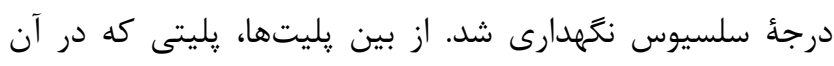

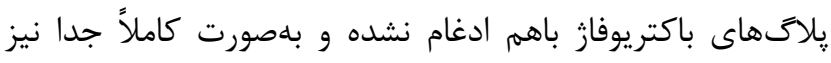

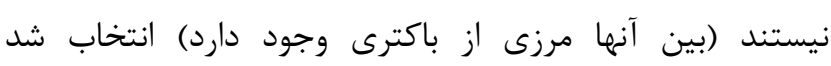

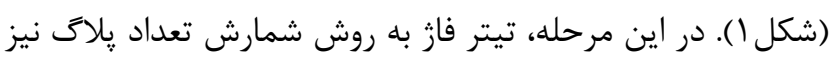

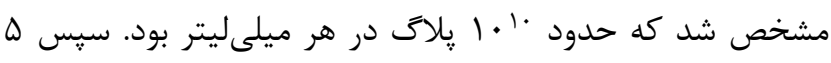

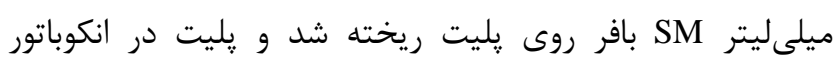

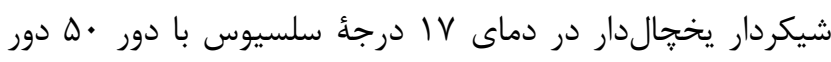

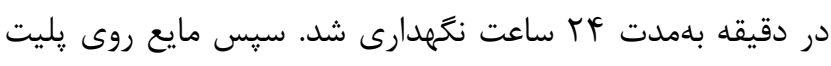

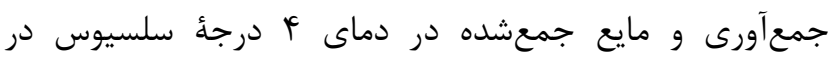

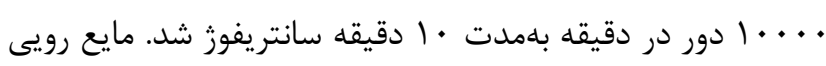




\section{روش آمارى}

آزمايشها، در حداقل حاقل سه تكرار انجام شد. اطلاعات

بهدستآمده، از طريق نرمافزار Windows, GraphPad Software, San Diego California و ANOVA تجزيهوتحليل شد. تحليل واريانس با روش USA)

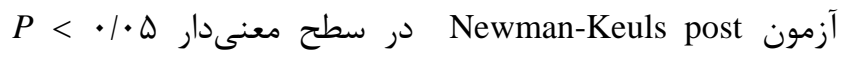

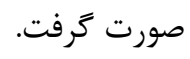

يافتهها

نتايج اثرات باكتريوفاز ST38 و بنزوآلكانيوم كلرايد بر بيوفيلم

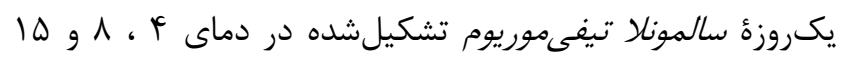

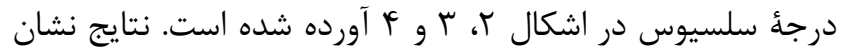

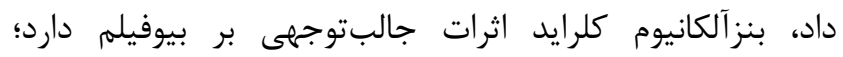

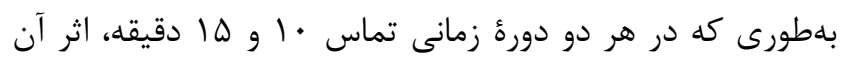

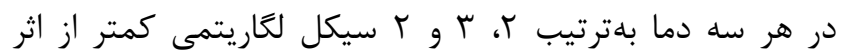
باكتريوفاز استفادهده بود. بين تشكيل بيوفيلم در دماى أل، م و و

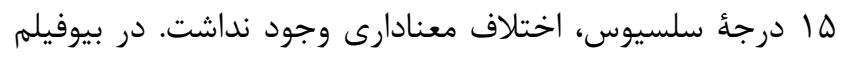

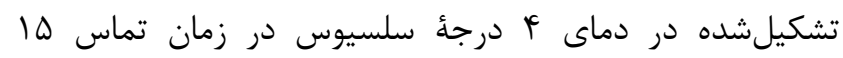

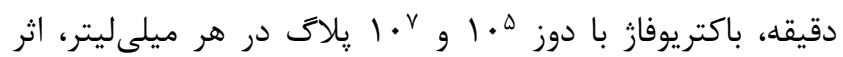

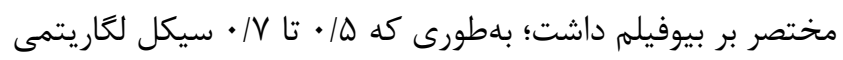

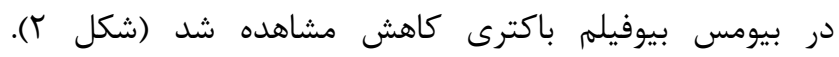

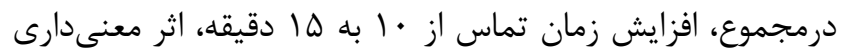

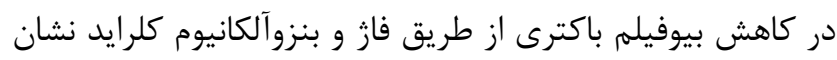

برداشته و به يك براث گوشت تازه بدون باكترى منتقل مىشدند

\section{اثرات فاز بر كلنىهاى داراى بيوفيلم}

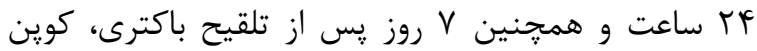

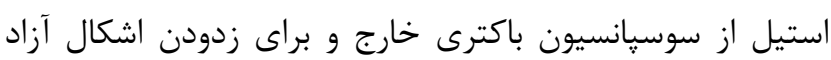

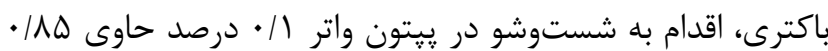
درصد كلريد سديم شد. در مرحلة بعد، كوينها طى فوراصل زمانى دانى

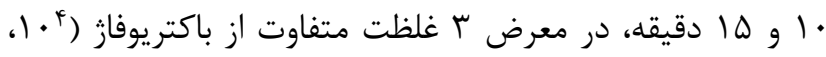

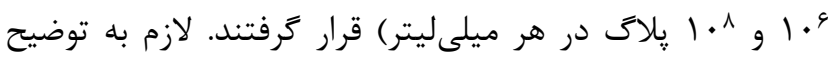

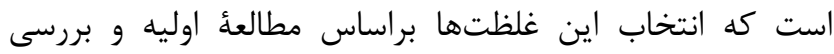
غلظتهاى مختلف بود. در مرحلئ بعد و براى تعاى تعيين اثرات

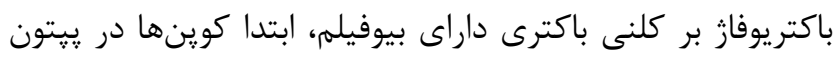

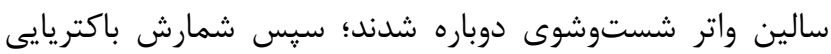

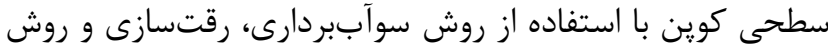
يخش خطى (Track) در محيط كشت آتار لوريا برتانى تعيين شد.

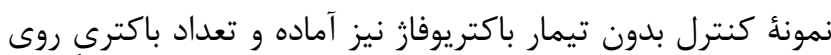

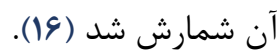

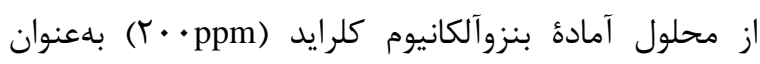
مادة معمول ضدعفونى كنندة كاربردى در صنايع غذايى، بلهن إعنوان

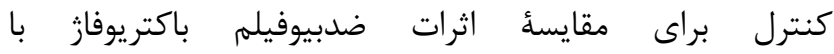

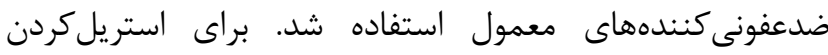

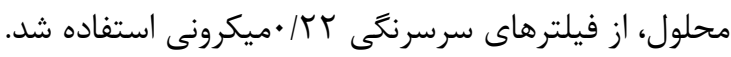

نداد.

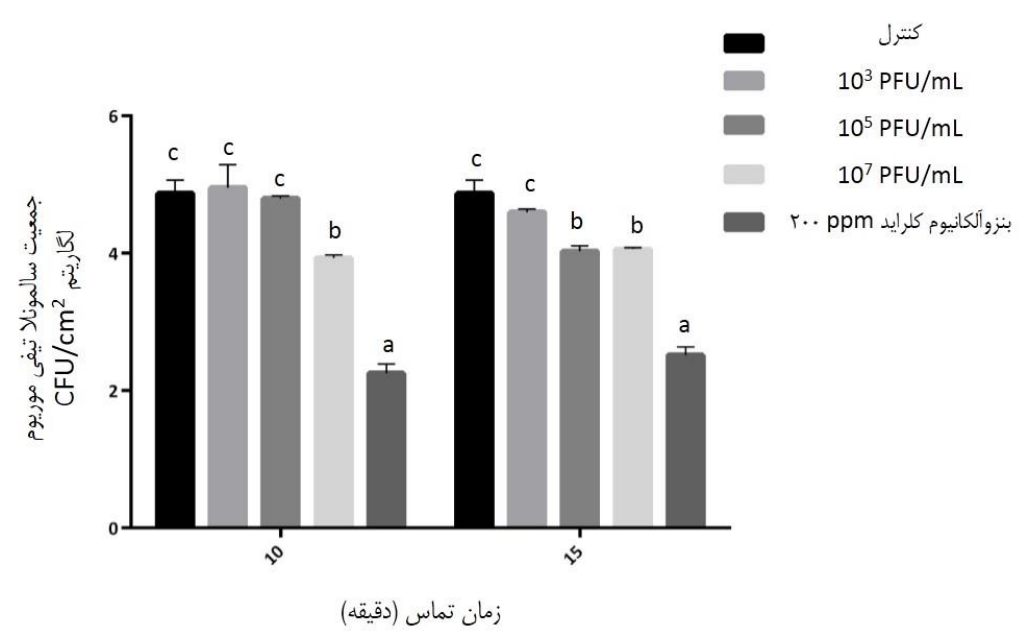

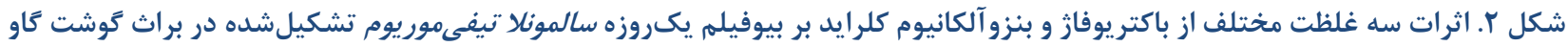

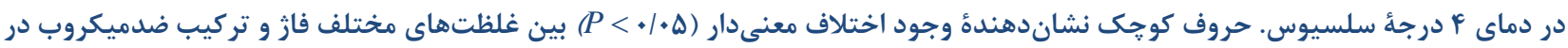
هر زمان تماس است. 


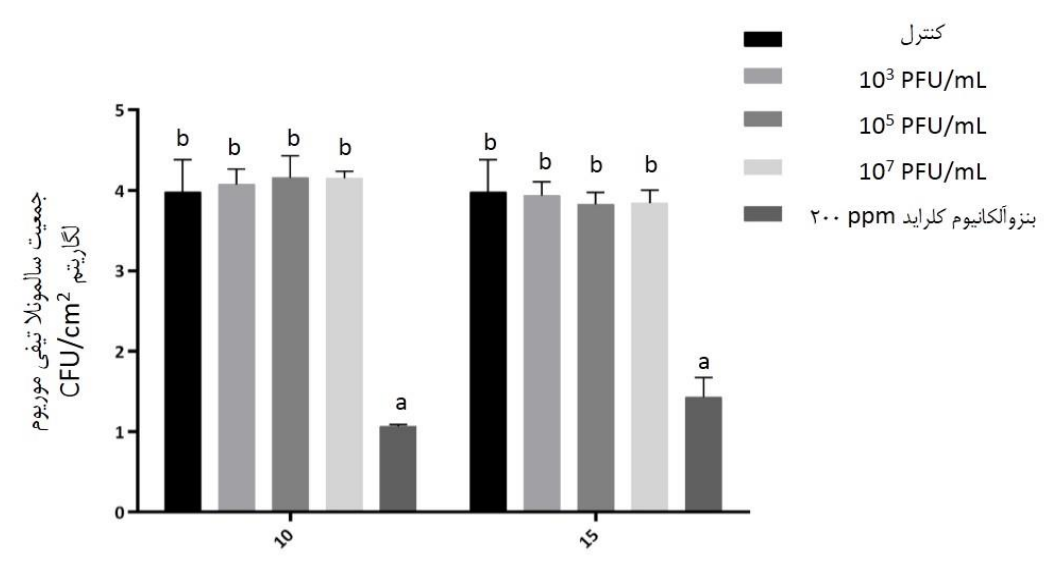

زمان تماس (دقيقه)

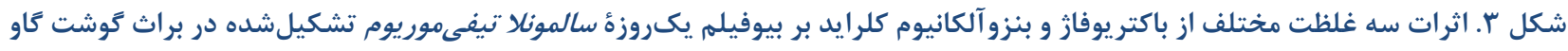

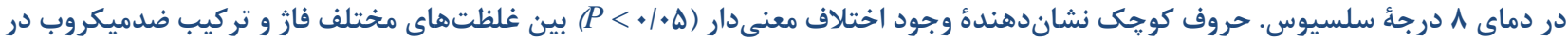
هر زمان تماس است.

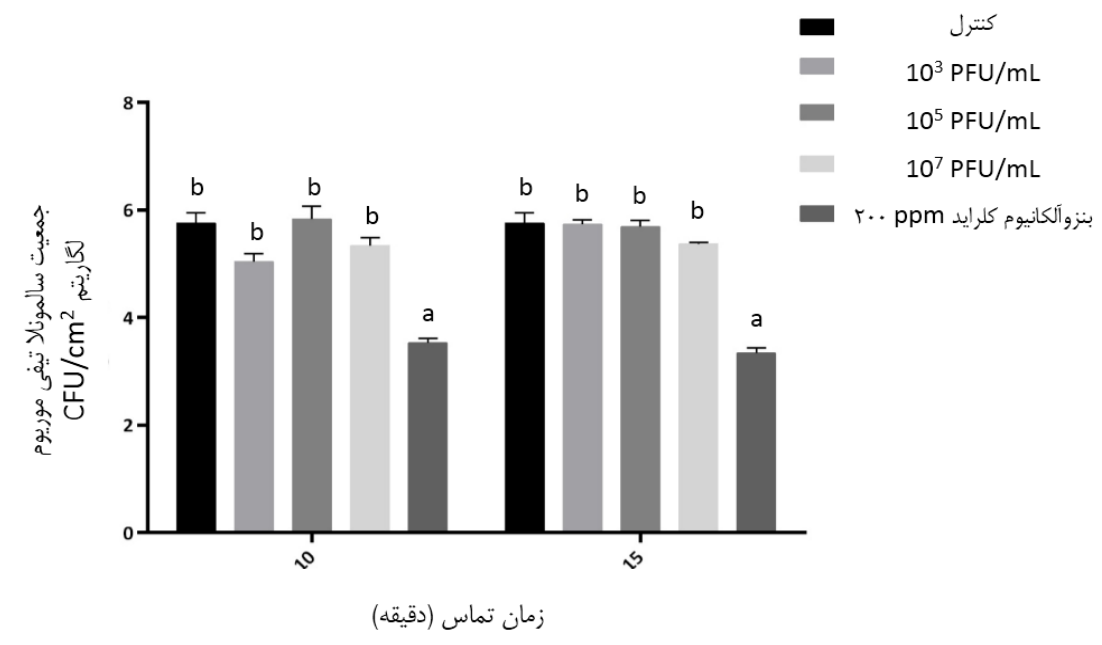

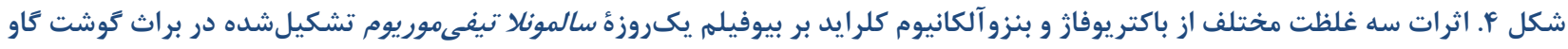

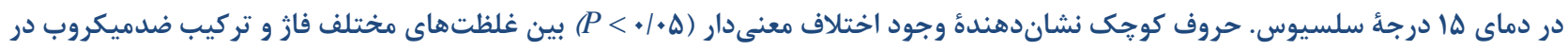
هر زمان تماس است.

مربوط به باكتريوفاز كمتر از ه/ • سيكل لكاريتمى با نمونهُ كنترل

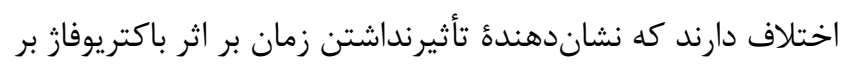

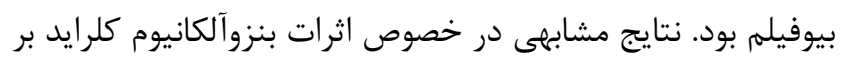

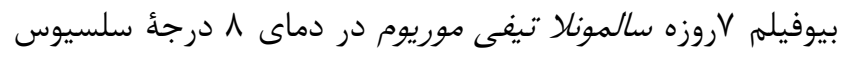

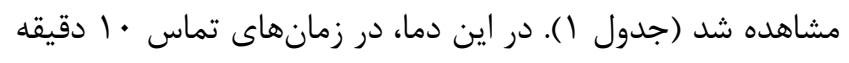

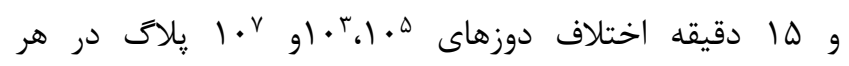

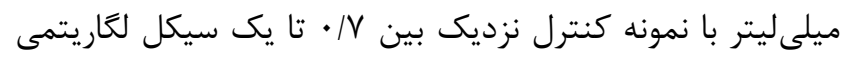

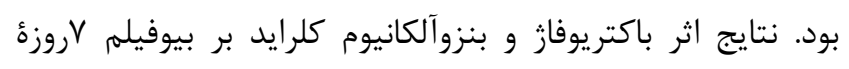

در جدول ا، نتايج مربوط به اثرات باكتريوفاز بر بيوفيلم

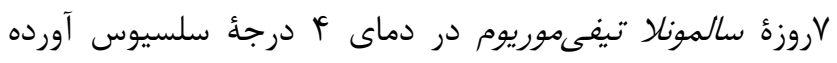

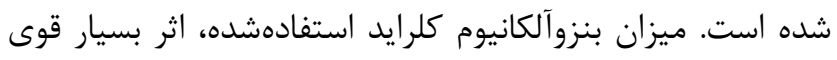

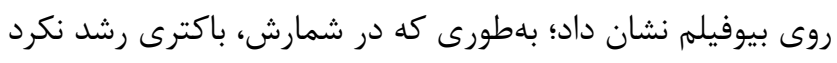

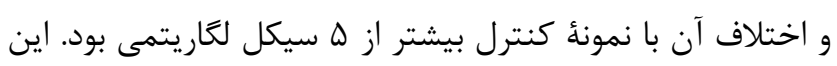

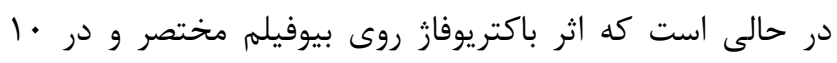

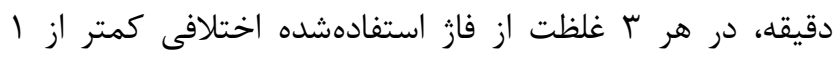

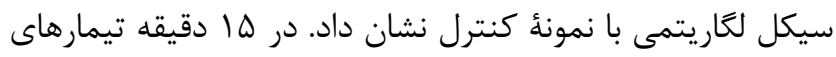




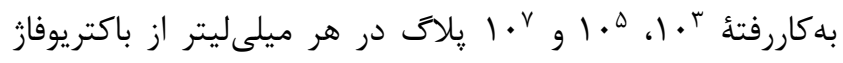
نشاندهندة تأثير كذار نبودن فاز بر بيوفيلم در اين دما بود. بارئ

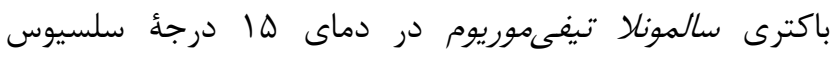

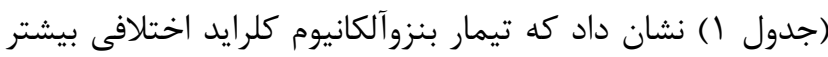
از 1 سيكل لكاريتمى با نمونهٔ كنترل دارد. نتايج غلظتهاى داري

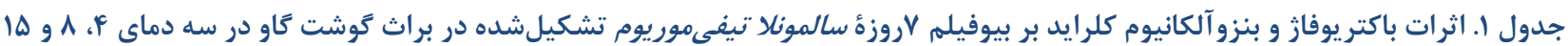

درجئ سلسيوس

\begin{tabular}{|c|c|c|c|c|c|c|}
\hline \multirow{2}{*}{ كلرايد بن بروآلكانيوم } & \multirow{2}{*}{ كنترل (بدون } & \multicolumn{3}{|c|}{ غلظت فاز (PFU/mL) } & \multirow{2}{*}{ تماس (دقزمان } & \multirow{2}{*}{ 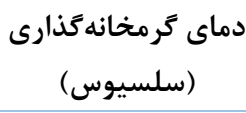 } \\
\hline & & $1 \cdot v$ & 1.0 & $1 . r$ & & \\
\hline صفر & $\Delta / \Delta \cdot \pm \cdot / 1^{b}$ & $p / p q \pm \cdot / V^{a}$ & $f / 9 q \pm \cdot / V^{a}$ & $f / 9 q \pm \cdot / T^{\mathrm{a}}$ & 1 & \multirow{2}{*}{ f } \\
\hline صفر & $\Delta / \Delta \cdot \pm \cdot / /^{c}$ & $\varphi / / \Delta \pm \cdot /\left.\right|^{c a}$ & $\mathrm{f} / \Lambda \cdot \pm \cdot / \Lambda^{\mathrm{b}}$ & $\boldsymbol{c} / \boldsymbol{r} \pm \cdot / r^{\mathrm{a}}$ & 10 & \\
\hline صفر & $p / 9 q \pm \cdot / q^{c}$ & $\boldsymbol{c} / \cdot \boldsymbol{f} \pm \cdot / \Delta^{b}$ & & $r / 9 \Delta \pm \cdot / r^{b}$ & 1 . & \multirow{2}{*}{$\wedge$} \\
\hline صفر & $f / 9 q \pm \cdot / 9^{c}$ & $f / T^{\mu} \pm \cdot / f^{b c}$ & $|r| \pm \cdot / V^{a}$ & $f / 1 \varphi \pm \cdot \mid q^{b}$ & 10 & \\
\hline$\Delta / r q \pm \cdot / /^{a}$ & $G / \Delta r \pm \cdot / r^{b}$ & $q / T V \pm \cdot / \mu^{b}$ & $q|f| \pm \cdot \mid T^{b}$ & $q / F^{c} \pm \cdot /^{b}$ & $1 \cdot$ & \multirow{2}{*}{10} \\
\hline$\Delta / \cdot \varepsilon \pm \cdot / r^{\mathrm{a}}$ & $q / \Delta r \pm \cdot / r^{a}$ & $q|f| \pm \cdot / r^{a}$ & $g / V \mid \pm \cdot / 1^{\mathrm{a}}$ & $q / g r \pm \cdot /^{\mathrm{a}}$ & 10 & \\
\hline
\end{tabular}

روز را داشت كه احتمالاً به خاصيت فنوتيبى و يا زنوتيبى خاص اين جدايه مربوط مىشود.

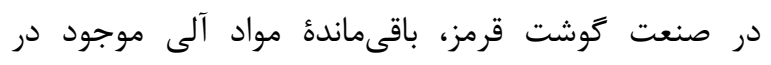

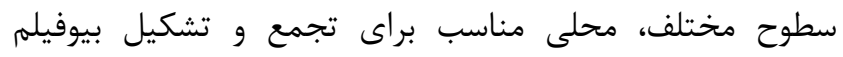
باكترى است و بلعنوان نقطهاى براى انتقال متقاطع مطرح است

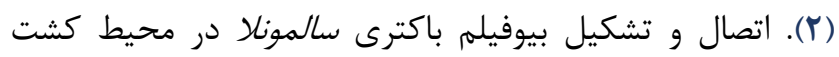

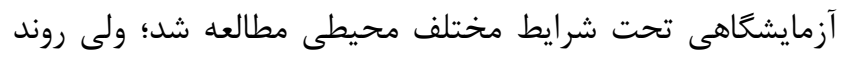

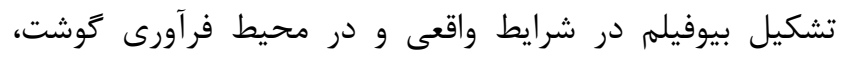

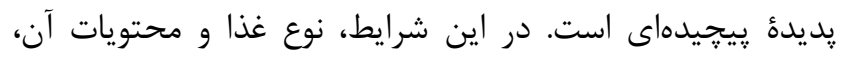

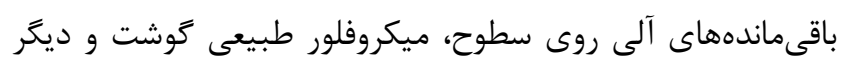

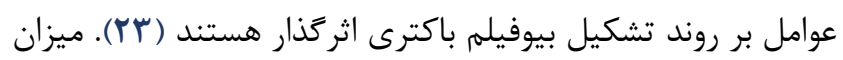

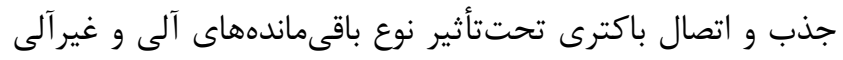

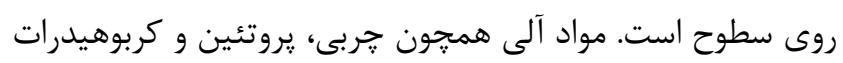

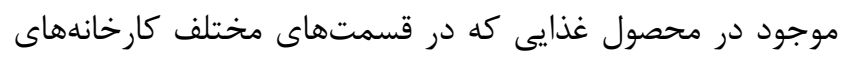

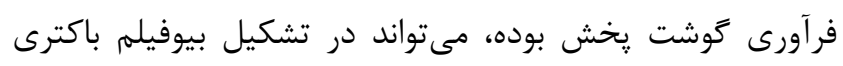

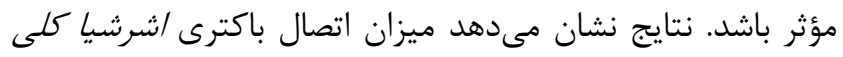

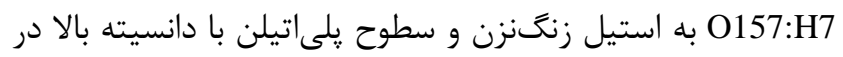

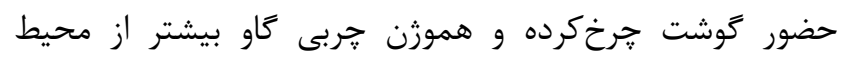

كشت است (r) (r).

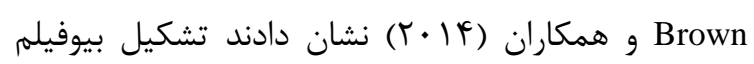

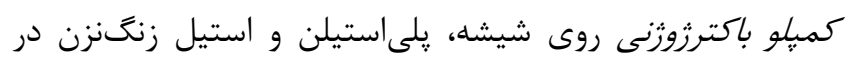

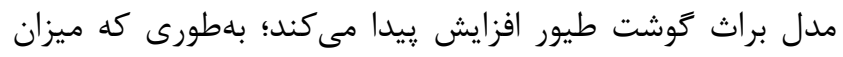

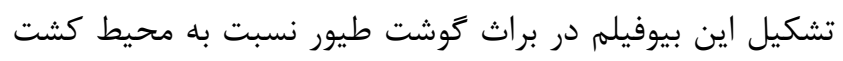

بحث

سالمونلا توانايى زيادى در تشكيل بيوفيلم در سطوح مختلف

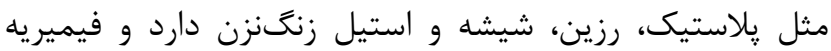

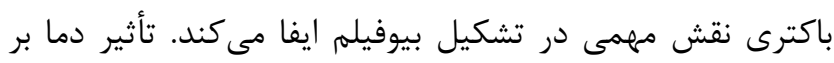

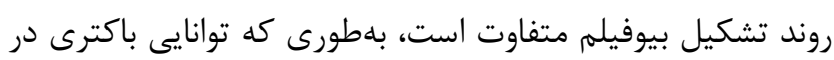

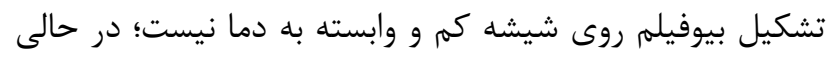

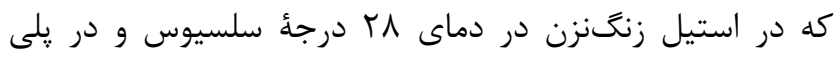

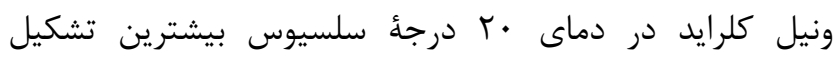

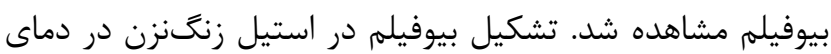

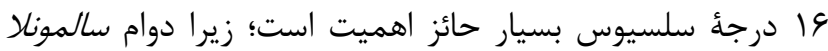

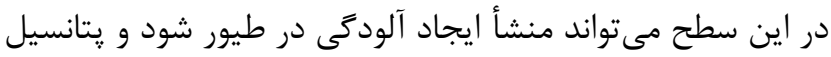

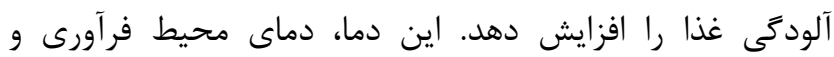

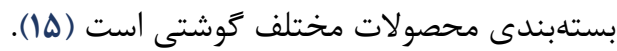

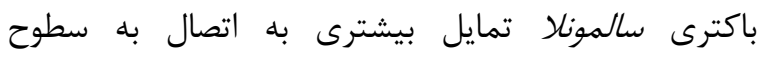

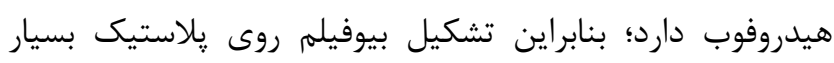

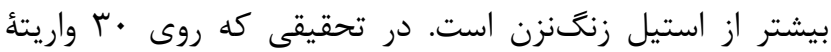

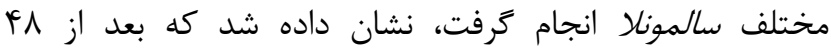

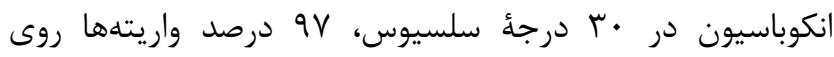

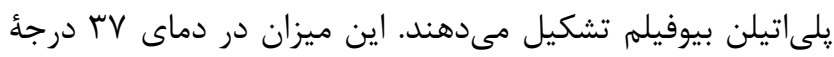

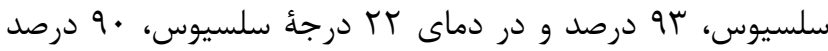

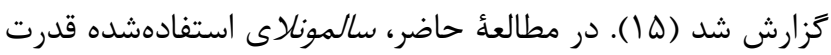

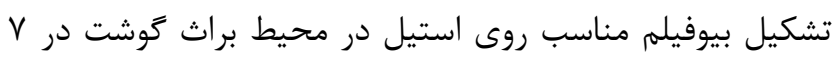


باكتريوفاز بر بيوفيلم، اين اثر درباره بيوفيلم لروزه بسيار ناجيز و

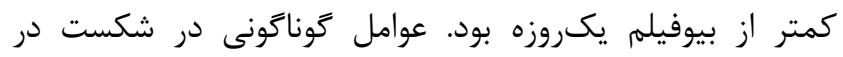

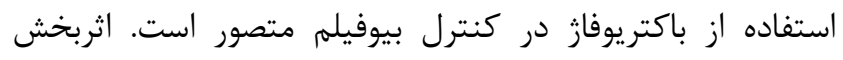

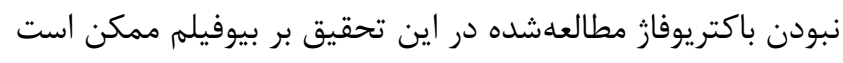

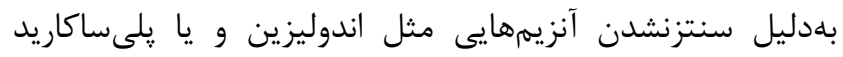

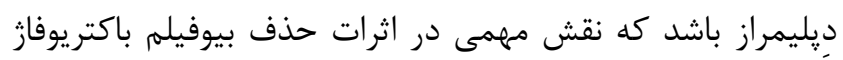

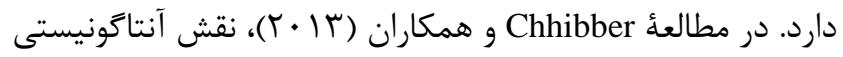
آهن بر اثربخشى باكتريوفاز عليه بيوفيلم باكترى كلبسيلا بِنومونيا

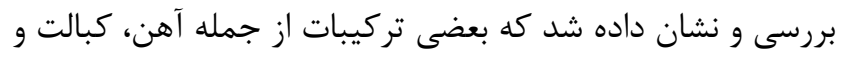

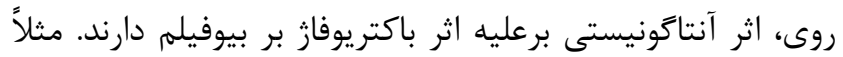

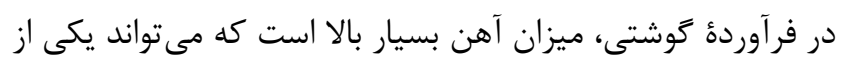

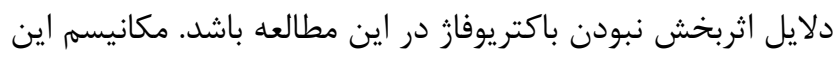

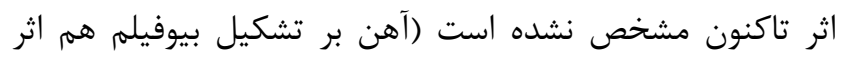

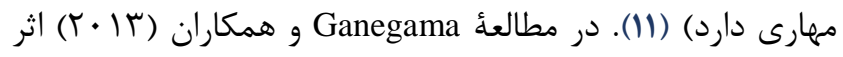

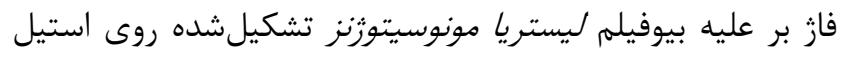

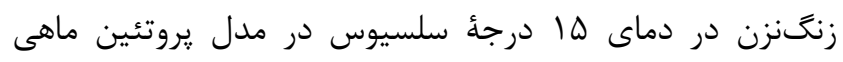

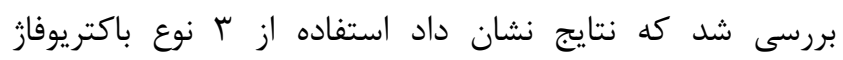

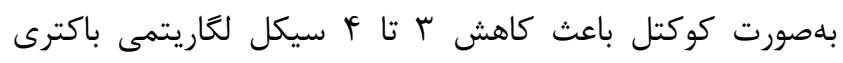

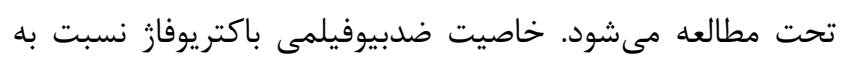

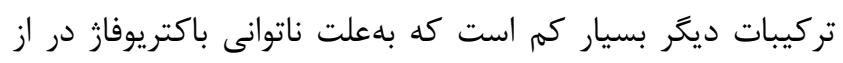

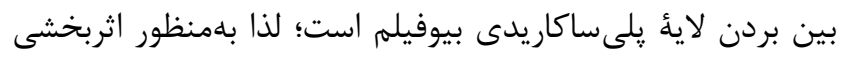

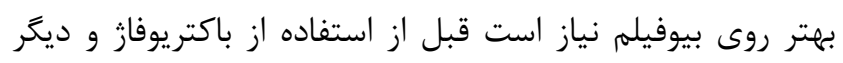

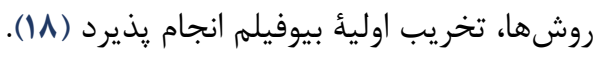

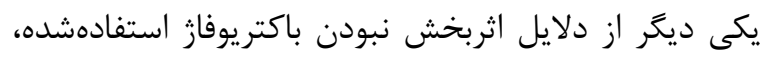

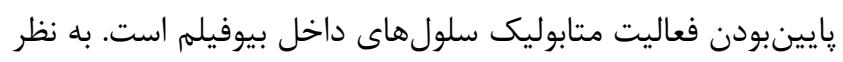

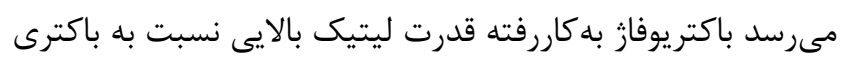

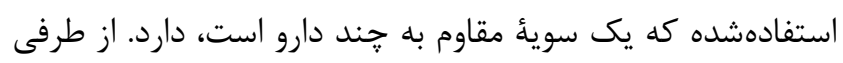

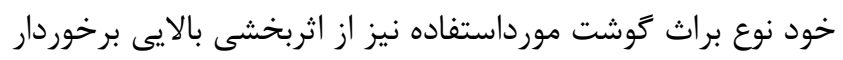

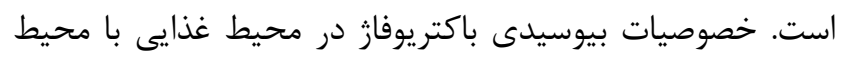

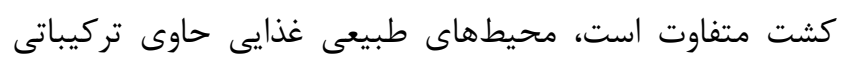

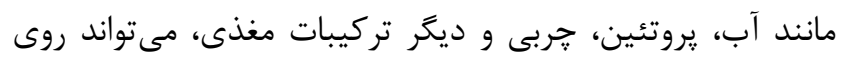

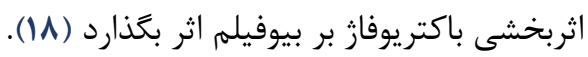

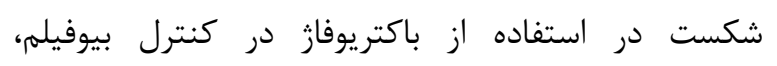

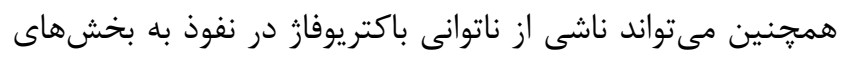

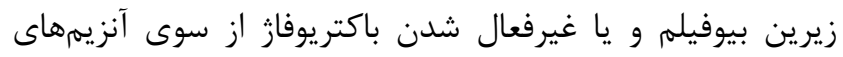

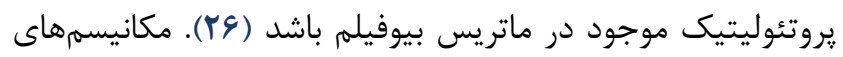

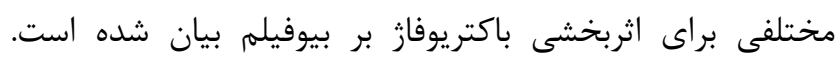

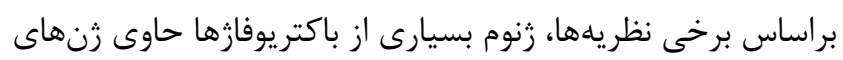

آزمايشًاهى بيشتر بود. اين يافته بيانكَر اين واقعيت است كه براث

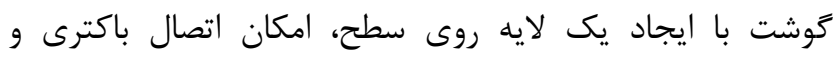

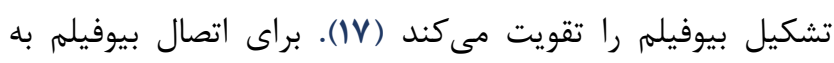

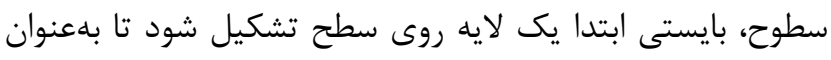

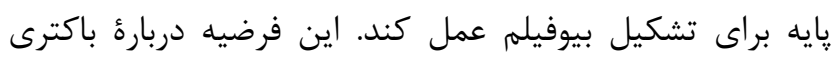

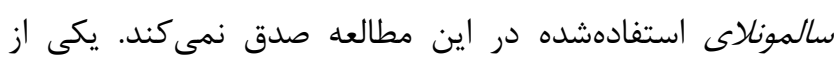

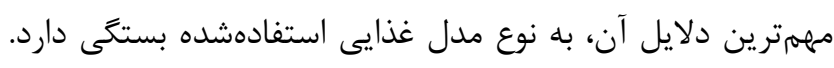

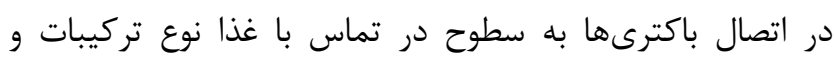

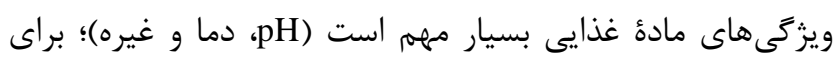

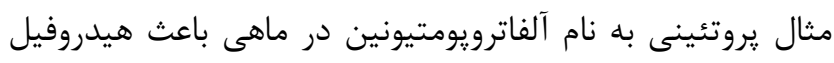
شدن سطح استيل مى شود؛ لذا اتصال باكترى به آن سطح رانئ رآ آسان

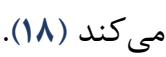

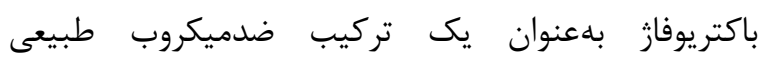

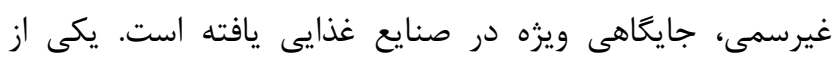

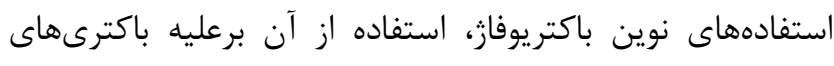

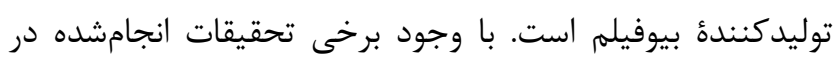

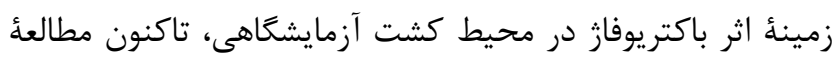

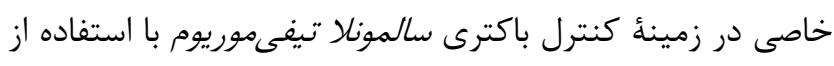

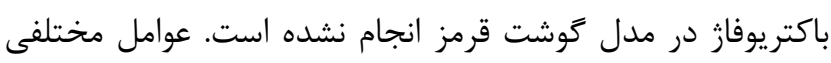

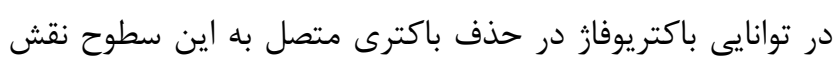

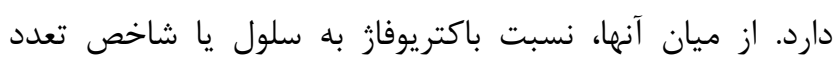

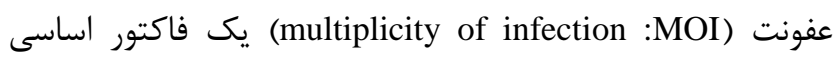

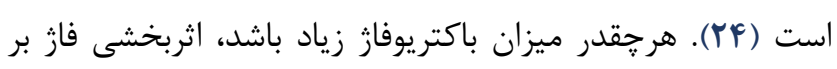

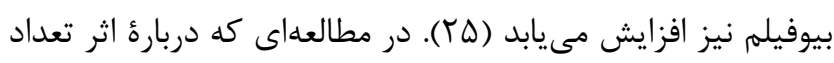

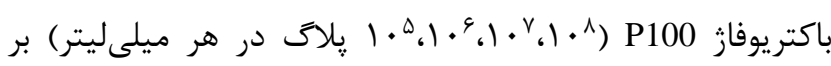

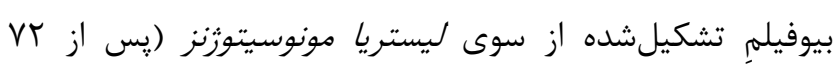

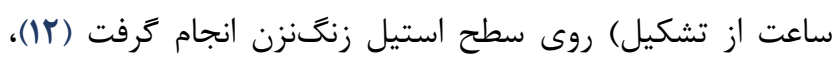
كاهش مشخصى در ميزان توده بيوفيلم به ميزان

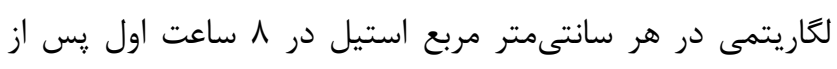

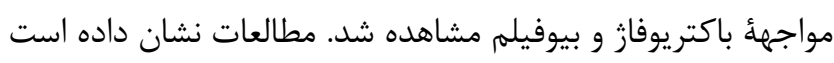

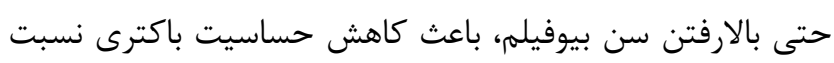

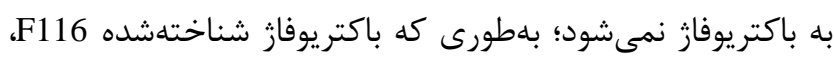

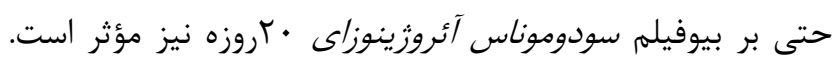

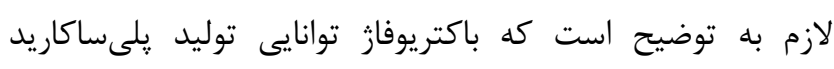

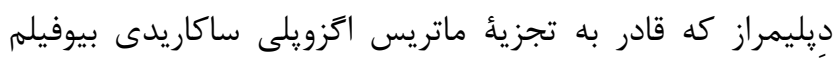

است را دارد (1).

نتايج مطالعهٔ حاضر نشان داد كه اثربخشى باكتريوفاز روى

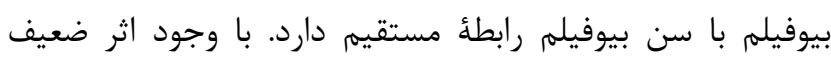


است كه نشان مىدهد بلوغ در بيوفيلم باعث مقاومتر شدن ساختار

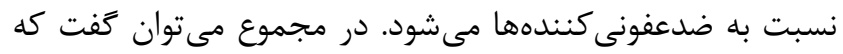

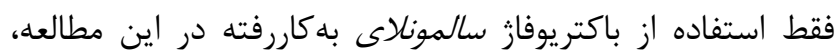

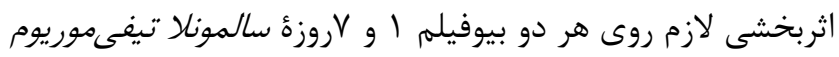

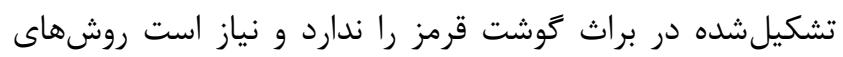
تركيبى ديكر همراه با باكتريوفاز به كار رود و يا استفاده از كوكتل

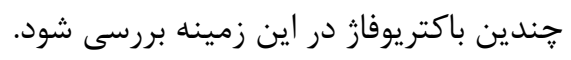
سياسگزارى

نويسند بهخاطر همكارى و تأمين بودجئ اجراى اين يزروهش كمال امتنان

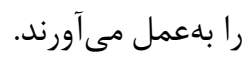
تعارض منافع بين نويسندگان تعارض در منافع گزارش نشده است.

\section{References}

1. Harper D, Parracho H, Walker J, Sharp R, Hughes G, Werthén $M$, et al. Bacteriophages and biofilms. Antibiotics. https://doi.org/10.3390/antibiotics3030270 PMCID:PMC4790368

2. Srey S, Jahid IK, Ha S-D. Biofilm formation in food industries: A food safety concern. Food Control. 2013;31(2):572-85.

https://doi.org/10.1016/j.foodcont.2012.12.001

3. Giaouris E, Heir E, Hébraud M, Chorianopoulos N, Langsrud S, Moretro $\mathrm{T}$, et al. Attachment and biofilm formation by foodborne bacteria in meat processing environments: causes, implications, role of bacterial interactions and control by alternative novel methods. Meat Sci. 2014;97(3):298-309. https://doi.org/10.1016/j.meatsci.2013.05.023 PMID:23747091

4. Moretro T, Heir E, Nesse LL, Vestby LK, Langsrud S. Control of Salmonella in food related environments by chemical disinfection. Food Res Int. 2012;45(2):532-44. https://doi.org/10.1016/j.foodres.2011.02.002

5. Paulson DS. Applied biomedical microbiology. CRC Press/Taylor \& Francis; 2010.

6. Arnold JW. Biofilms in poultry processing. In: Fratamico PM, Annous BA, Gunther NW (Eds). Biofilms in the Food and beverage industries. Sawston, Cambridge: Woodhead Publishing; 2009. p.455-73.

7. Habimana O, Heir E, Langsrud S, Asli AW, Moretro T. Enhanced surface colonization by Escherichia coli

$$
\begin{aligned}
& \text { آنزيمهايى هستند كه توانايى تخريب مواد موجود در ماتريس } \\
& \text { بيوفيلم را دارند. اين آنزيمها اغلب محلول در آب بوده و پيس از }
\end{aligned}
$$

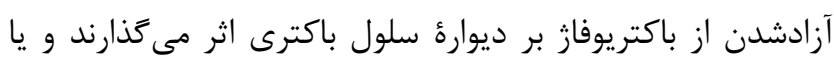

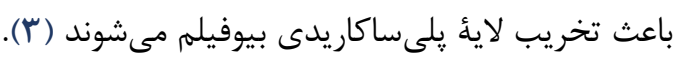

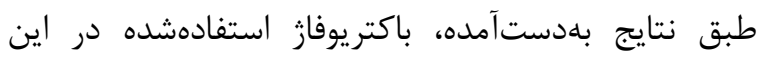

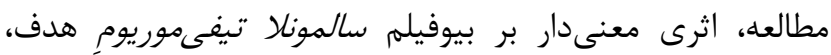

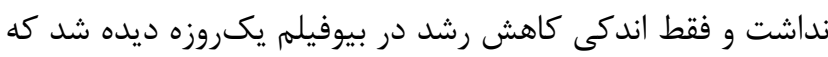

$$
\begin{aligned}
& \text { مىتواند ناشى از بلوغ ناكافى بيوفيلم و اگزويلى ساكاريد جوان }
\end{aligned}
$$

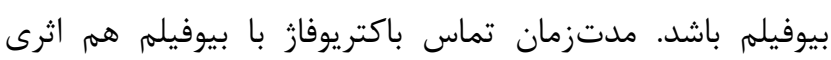

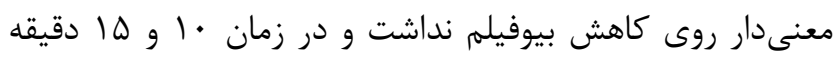

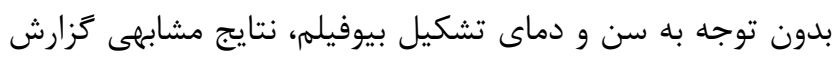

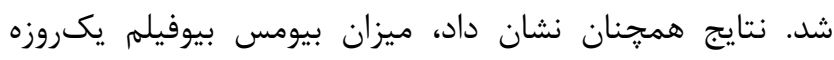

$$
\begin{aligned}
& \text { بهمراتب كمتر از بيوفيلم لروزه است كه نشان از رشد و بلوغ } \\
& \text { بيوفيلم در طول زمان دارد. اثر بنزوآلكانيوم كلرايد در بيوفيلم }
\end{aligned}
$$

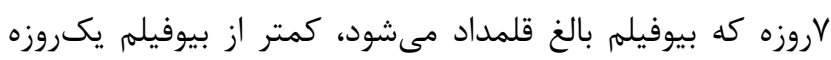

O157:H7 in biofilms formed by an Acinetobacter calcoaceticus isolate from meat-processing environments. Appl Environ Microbiol. 2010;76(13):4557-9. https://doi.org/10.1128/AEM.02707-09

\section{PMID:20453142 PMCID:PMC2897464}

8. Mukhopadhyay S, Ramaswamy R. Application of emerging technologies to control Salmonella in foods: A review. Food Res Int. 2012;45(2):666-77. https://doi.org/10.1016/j.foodres.2011.05.016

9. Sillankorva SM, Oliveira H, Azeredo J. Bacteriophages and their role in food safety. Int $\mathbf{J}$ Microbiol. 2012;2012:863945. https://doi.org/10.1155/2012/863945 PMID:23316235 PMCID:PMC3536431

10. Razavi Rohani SM, Moradi M. Food application of natural antimicrobial compounds. Tehran: Jahad Daneshghahi Publishing; 2017. p.225-9.

11. Chhibber S, Nag D, Bansal S. Inhibiting biofilm formation by Klebsiella pneumoniae B5055 using an iron antagonizing molecule and a bacteriophage. BMC Microbiol. 2013;13(1):174. https://doi.org/10.1186/14712180-13-174 PMID:23889975 PMCID:PMC3726515

12. Monta-ez-Izquierdo VY, Salas-Vázquez DI, Rodríguez-Jerez JJ. Use of epifluorescence microscopy to assess the effectiveness of phage P100 in controlling Listeria monocytogenes biofilms on stainless steel surfaces. Food Control. 2012;23(2):470-7. https://doi.org/10.1016/j.foodcont.2011.08.016

13. Gabisoniya TG, Loladze MZ, Nadiradze MM, Chakhunashvili NK, Alibegashvili MG, Tamarashvili $\mathrm{NG}$, et al. Effects of bacteriophages on biofilm formation by strains of Pseudomonas aeruginosa. Prikl Biokhim 
$\begin{array}{lcc}\text { Mikrobiol. } & \text { 2016; } & \text { 52(3): } \\ \text { https://doi.org/10.1134/S000368381603004 }\end{array}$ PMID:29509387

14. Gutierrez D, Fernandez L, Martinez B, Ruas-Madiedo P, Garcia P, Rodriguez A. Real-time assessment of Staphylococcus aureus biofilm disruption by phagederived proteins. Front Microbiol. 2017;8:1632. https://doi.org/10.3389/fmicb.2017.01632 PMID:28883818 PMCID:PMC5573737

15. De Oliveira DCV, Fernandes Júnior A, Kaneno R, Silva MG, Araújo Júnior JP, Silva NCC, et al. ability of salmonella spp. to produce biofilm is dependent on temperature and surface material. Foodborne Pathog Dis. 2014;11(6):478-83.

https://doi.org/10.1089/fpd.2013.1710 PMID:24720488

16. Duong HNN, Formation of Salmonella Typhimurium biofilm under various growth conditions and its sensitivity to industrial sanitizers [dissertation]. Lower Kent Ridge Rd, Singapore: National university of Singapore; 2012.

17. Brown HL, Reuter M, Salt LJ, Cross KL, Betts RP, van Vliet AH. Chicken juice enhances surface attachment and biofilm formation of Campylobacter jejuni. Appl Environ Microbiol. 2014;80(22):7053-60.

https://doi.org/10.1128/AEM.02614-14

PMID:25192991 PMCID:PMC4249011

18. Ganegama Arachchi GJ, Cridge AG, DiasWanigasekera BM, Cruz CD, McIntyre L, Liu R, et al. Effectiveness of phages in the decontamination of Listeria monocytogenes adhered to clean stainless steel, stainless steel coated with fish protein, and as a biofilm. J Ind Microbiol Biotechnol. 2013;40(10):1105-16. https://doi.org/10.1007/s10295-013-1313-3

PMID:23907252

19. Ghasemmahdi H, Tajik H, Moradi M, Mardani K, Modaresi R, Badali A, et al. Antibiotic resistance pattern and biofilm formation ability of clinically isolates of Salmonella enterica serotype typhimurium. Int J Enteric Pathog. 2015;3(2):e27372. https://doi.org/10.17795/ijep27372

20. Clokie MRJ, Kropinski AM. Bacteriophages, methods and protocols. New York: Springer Publishers: 2009.

21. Kim SH, Wei CI. Biofilm formation by multidrugresistant Salmonella enterica serotype Typhimurium phage type DT104 and other pathogens. J Food Prot. 2007;70(1):22-9. https://doi.org/10.4315/0362-028X70.1.22 PMID: 17265855

22. Valeriano C, de Oliveira TLC, de Carvalho SM, Cardoso MdG, Alves E, Piccoli RH. The sanitizing action of essential oil-based solutions against Salmonella enterica serotype Enteritidis S64 biofilm formation on AISI 304 stainless steel. Food Control. 2012;25(2):673-7. https://doi.org/10.1016/j.foodcont.2011.12.015
23. Dourou D, Beauchamp CS, Yoon Y, Geornaras I, Belk $\mathrm{KE}$, Smith GC, et al. Attachment and biofilm formation by Escherichia coli $\mathrm{O} 157: \mathrm{H} 7$ at different temperatures, on various food-contact surfaces encountered in beef processing. Int J Food Microbiol. 2011;149(3):262-8. https://doi.org/10.1016/j.ijfoodmicro.2011.07.004 PMID:21802758

24. Carpentier B. Biofilms in red meat processing. In: Fratamico PM, Annous BA, Gunther NW, editors. Biofilms in the food and beverage industries. Sawston, Cambridge: Woodhead Publishing; 2009. p.375-95.

25.http://www.efsa.europa.eu/EFSA/DocumentSet/Zoon_r eport.

26. Doolittle MM, Cooney JJ, Caldwell DE. Tracing the interaction of bacteriophage with bacterial biofilms using fluorescent and chromogenic probes. J Ind Microbiol. 1996;16(6):331-41.

https://doi.org/10.1007/BF01570111 PMID: $\underline{8987490}$ 